\title{
Social Responsibility within Thinking about Forgiveness
}

\author{
ThDr. Mgr. Slávka Michančová, PhD. \\ University of Prešov in Prešov, Faculty of Greek-Catholic Theology
}

\section{Introduction}

Referring to Biblical texts (e.g. Mth 5:43-48; Lk 6:27-38), Christianity puts great emphasis on love toward all people, even toward enemies. Where sin appears and causes harm, damage or conflict, believers are encouraged to forgiveness and reconciliation. This challenge is often expressed within sermons, pastoral dialogs, articles in Christian magazines, lectures, prayers for inner healing, or within the religious language of the family. However, it usually stays on the level of general phrases, without clear explanation: what does forgiveness and reconciliation mean, what does it consist of, what is the role or task for the victim, for the offender and for the community.

So it is not surprising that many believers create simplified opinions on forgiveness and reconciliation, which are very dangerous because they can (directly or indirectly but really) multiply suffering and support violence. Under the cover of Christian love there are often hidden such unchristian motives as denying of truth, laziness, cowardess, fear from stirring up a conflict, impatience, lack of love toward self, dependence on the offender, ...

Once the forgiveness and reconciliation are presented as possible, or obligatory, or the best and most important things to do, without any reminder of disclosure, punishing and repentance of the offender, then it easily distracts the attention from the core of the problem of crime and harm, and becomes part of the problem rather then its solution. ${ }^{1}$

In an atmosphere full of mistaken attitudes, the question of forgiveness

\footnotetext{
${ }^{1}$ Cp. ARMS, M. F.: When Forgiveness Is Not the Issue in Forgiveness. pg. 107-128. In: FORTUNE, M. M. - MARSHALL, J. L. (Eds.): Forgiveness and Abuse. New York: The Haworth Pastoral Press, Inc., 2002, pg. 108-110; HORSFIELD, P.: Forgiving Abuse - An Ethical Critique. pg. 51-70. In: FORTUNE, M. M. - MARSHALL, J. L. (Eds.) Forgiveness and Abuse. New York : The Haworth Pastoral Press, Inc., 2002, pg. 54-55.
} 
and reconciliation becomes a rich source of a false sense of guilt and an unauthorized critique of victims. In contemporary Christian practice, the burden of forgiveness and reconciliation is nearly always put on the shoulders of victims, while the others stay in the comfort of doing nothing and in hypocrisy; the offenders deny their guilt, they are not held responsible and burdened with the demand for repentance. Such a non-complex attitude is surely not biblical. We refer to merciful love; but we forget that without the relation to justice and truth, love fails to serve life and healing. ${ }^{2}$

In this article I will try to point out some mistaken concepts of forgiveness and reconciliation and offer a more sensitive and complex solution in the context of crime and trauma. First however, it is necessary to clarify the core of forgiveness, or what is it that is forgiven.

\section{The core of forgiveness}

I think that this core could be found in the parable of the unmerciful servant (Mth 18: 23-35). Jesus tells the parable about the master who called his servant to show him his debt that was so high that he would not be able to pay it off until the end of his life. At the same time the master showed him how rough he could deal with him because of his claim for payment of the debt. When the debtor heard this, he had to feel dismay and fear because he immediately started to beg for relief and promised to pay everything off. The master had mercy on him; he let him go and even forgave him his debt.

Let us note that the master forgives what the servant is not able to pay off by his own ability under any circumstances. So I can state that what is forgiven is in fact what could not be paid off. The part that still remains is in fact a challenge to repentance - as when Jesus forgives sins and adds: Go and not sin any more!" (John 8:11b). By this he challenges a sinner to change his present life and not create new debts; he asks the sinner to show a sincere effort to leave old way of life. Even the most perfect repentance can never undo (repair) the damage once done - but it does not mean that the repentance is useless - on the contrary repentance is a manifestation of remorse over the damage caused in the past and an expression of the will not to harm any more.

For this present moment the master also gives up the right to revenge. But when face to face with such mercy, the heart of the one who created such a huge debt will not learn to love in a better way (as it happened to the servant in the parable), the disappointed and angry master will at the end insist that he pay off the whole debt.

\footnotetext{
${ }^{2}$ Cp: ARMS, M. F.: When Forgiveness Is Not the Issue in Forgiveness. In: FORTUNE, M. M. - MARSHALL, J. L. (Eds.): Forgiveness and Abuse. New York: The Haworth Pastoral Press, Inc., 2002, pg. 108-110; ALLENDER, D. B. - LONGMAN III, T.: Pravá tvár lásky. Bratislava : Porta Libri, 2004, pg. 17.
} 
In this context it is appropriate to mention that the Bible puts great emphasis on repentance in connection with forgiving sin: Jesus addressed a "woe" to unrepentant people - he said that without repentance they will not prevail in front of God's judgment and will end in hell (see Mth 11: 20-24). The same message could be found in the Apostle's letters (see Rom 2:4-7; 2 Pt 3: 9) and in the Revelation of Saint John (see Rev 2:21-23; $16: 9-11 ; 3: 1-3)$. At different place Jesus tells that if we will not bring the fruits of repentance we will die (see Luke 13:1-9). The Apostles also speaks about forgiveness in relation to the necessity of conversion and doing repentance for the sins committed (see Acts 2:37-38; 8:22; 26:18.20; see also 1 John 1:9).

In analyzing the parable we can notice that the master shows mercy toward the debtor before any real change on the part of the debtor happened (the debtor's promises of restitution were just empty words). So the master's forgiveness is unconditional - at least in a sense that it is prepared before the servant is prepared to receive it honestly. Forgiveness is a gift offered to one who did not do anything to deserve it; in fact one could do nothing to deserve it. Even through repentance we could not deserve forgiveness; in fact repentance itself could not erase / delete the harm and damage once done. Repentance does not create any right to forgiveness - that is pure act of benevolence. ${ }^{3}$

However there is some relation between giving and receiving forgiveness: While giving forgiveness is not conditioned by repentance - only through repentance one can receive the forgiveness which always was there. So God forgave us already; his forgiveness is always available, but only if we turn toward him with repentance; then we can start using this forgiveness. In connection to this the Catechism of Catholic Church (in article no. 1847) states: To receive God's mercy, we have to admit / acknowledge our sins first." In any case, it is not possible to receive forgiveness and stay in unrepent-fullness. If man hopes to receive forgiveness without conversion and reach heaven without any personal effort - it is a manifestation of conceit or temerarious calculating of God's mercy (compare Catechism 2092; 982).

Repentance is really necessary for receiving forgiveness. If the sinner denies or does not regret his sin and debt created by it then he does not confess sincerely the need of forgiveness. So he could not receive forgiveness if he behaves as if he would not need it, as if he would be guiltless. In addition if he would not have a sincere interest to change himself - forgiveness would be useless because at the end all his debts would be counted up anyway. In fact without repentance the sinner can not receive the gift of forgiveness (in a valid and effective way) and reach real reconciliation.

\footnotetext{
${ }^{3}$ Cp. WOLBERT, W.: Odpušteni a sebeúcta. 2002, [online], [cited 2003-11-17], http://www.te ologicketexty.cz/issue/2002/2-3/wolbert.xml>.
} 
Through the parable about unmerciful servant I also want to point out that the term "unconditional forgiveness" that is often used in Christian circles could be easily misunderstood. I explained already that receiving forgiveness has its conditions. But the fact is that giving forgiveness is also conditioned - its conditions are truth and justice. Remember how the master allowed his servant to come to him and confronted him with the truth about his debt and the right to enforce paying of the debt. For both sides it surely was a painful and cruel truth. But only after the damage caused was named and the desire for revenge expressed was the debtor released together with the undeserved gift (or offer) of forgiveness. We have to remember that God is both merciful and just - and even if we do not know the accurate relation between these two attributes, we can not deny their mutual interconnection.

\section{Basic conditions regarding forgiveness}

If we speak about conditions of giving forgiveness we should realize one more significant fact. While God forgives in the context of eternity, human forgiveness happens in the context of time and space. God's forgiveness is always and constantly prepared because God is not liable to the laws/relations of time and space. God clearly recognizes the sin and the damage caused, experiences pain and anger, has mercy and offers forgiveness - all in one eternal moment. However in the human context forgiveness is a process. Additionally, God as the perfect being forgives out of himself - but man needs God's grace to be able to forgive; he is not able to do it out of his own strength. And God's grace usually builds on the natural laws of the process of forgiveness ${ }^{4}$; it does not cancel this process, just accompanies man on it and reinforces him on the journey.

In the usual talks about forgiveness in Christian circles, people often forget the core and conditions of forgiveness and reduce the content of the parable to the scaring message: As God forgave a huge debt to each and every-one of us, we should also forgive our debtors. If we would not forgive, we will not be forgiven by God... Usually no word about the context of truth and justice is mentioned.

Such curtailed teaching about forgiveness, together with other myths about forgiveness and reconciliation raises / triggers needless feelings of anxiety, fear, failure and guilt. I think that many people who have been deeply hurt by the sins of other people (especially victims of abuse and violence) need to clarify what forgiveness consists of.

My basic idea is that forgiveness is a process that is realized in the context of justice - while the essential component of justice is truth.

The first and necessary component of the forgiving process is getting rid of the denial of the truth. Various forms of denial belong to psycho-

\footnotetext{
${ }^{4}$ Cp.: McMANUS, J.: Healing in the Spirit. Hampshire : Redemptorist Publications, 2002, pg. 195.
} 
logical defense mechanisms that could be useful for the victim for some period of time enabling her to survive, but from a long-term perspective they could prevent her from facing the truth that has to be worked through. But without acknowledgement of reality - without remembering, without recognition and naming evil and without admitting the damage caused - forgiveness is not possible. In this regard, it is useful to point out on some common myths about forgiveness.

\section{Toward clarifying the process of forgiveness}

There is often a tendency to identify forgiveness with forgetting. Forgiveness however does not mean forgetting. ${ }^{5}$ Our memory, our ability to remember, has indispensable meaning and function for our life as well as some laws. When somebody was traumatized by one's deeds, the experience is stored in the memory in an especially strong and vivid way and could be triggered against the victim's will or desire not to remember any more. To ask victims to forgive and forget is not only misleading but also insensitive because it creates false feelings of guilt from not forgiving. In addition, forgetting is the most incorrect request because the process of healing and forgiving demands integration not repression of memories. ${ }^{6}$ The more the victim is conscious of what happened to her and how it influenced her and the more she is able to speak about it, the more freedom from the past she acquires. Trauma is part of ones personal history trying to forget it through forgiveness is like trying to rub out the part of personal identity. From this perspective forgetting is not healthy but rather pathological. ${ }^{7}$

In addition, to forget and behave as if nothing bad happened is quite unwise, even unethical, in relation to the offenders. Memory plays an important role in the preparation toward confrontation and installing protective measures. Desmond Tutu writes in his book "There is no future without forgiveness" that in spite of forgiveness, it is important to remember not to allow crimes to happen again.

\footnotetext{
${ }^{5}$ Cp.: DONGHI, A.: Hle, všechno tvořim nové. Kostelní Vydří: Karmelitánske nakladatelství, 2002, pg. 85; WOLBERT, W.: Odpuštení a sebeúcta. 2002, [online], [cited 2003-11-17], http://www.teologicketexty.cz/issue/2002/2-3/wolbert.xml; FORTUNE, M. M.: Preaching Forgiveness? pg.49-57. In: McCLURE, J. S. - RAMSAY, N. J. (Eds.): Telling the Truth. Cleveland, Ohio : United Church Press, 1998; KESHGEGIAN, F.: Redeeming Memories. Nashville : Abingdon Press, 2000, pg. 195.

${ }^{6}$ Cp.: PARKINSON, P.: What Does Lord Require of Us? Melbourne : Paper for the Australasian Christian Legal Convention, February 2001, [online], [cited 2004-01-04], <http://www .cls.org.au/convention7.htm>.

${ }^{7}$ Cp.: BILICH, M. - BONFIGLIO, S. - CARLSON, S.: Shared Grace. New York : The Haworth Pastoral Press, 2000.

pg. 104-109; FORTUNE, M. M.: Violence in the Family. Cleveland : The Pilgrim Press, 1991, pg. 137-151.

${ }^{8}$ Cp. TUTU, D.: Bez odpustenia niet budúcnosti. Bratislava : Serafín, 2005, pg. 278.
} 
Forgetting is not biblical in the way some Christians think while quoting the verse from Jeremiah 31:34 (I will forgive their guilt and will not remember their sin any more). It is just a metaphor and we have no right to a literal understanding. The Bible teaches us that God remembers sins because one day each of us will stand in front of God's court... In a different regard the Bible also points out the importance of memory. Remembering significant traumatic events as well as God's redemptive activity is an integral part of the Old and New Testament religion (e.g. remembering the Egyptian slavery and the rescue from it; or the memory of the death and resurrection of Jesus Christ).?

Another wrong tendency is replacing forgiveness with remission. One can remit little things, everyday little mistakes or incidents which are morally indifferent (e.g. when somebody steps on my foot unintentionally). However to remit a crime would mean that nothing has happened, or nothing that bad. Such a remission would express that the immoral action was in fact not immoral, that violence or abuse was not in fact violence or abuse. Remission would lead to tolerating or accepting moral evil. Remission would not only ignore injustice but also minimize the damage caused. But only at the expense of self-deception it is possible to think that everything is OK. Real forgiveness clearly recognizes and names evil as well as the gravity / severity of the hurt and the extent of the damage caused. ${ }^{10}$

The tendency to interchange forgiveness and pardoning the offender is also connected to denial. But this form of the myth will be explained later. For the moment I would like to add that it is not easy to leave various forms of denial because they provide safe (although false) protection against cruel and painful truth. Moreover denial is often nourished by wrong attitudes of the surroundings. Not only a few victims get stuck in various forms of denial for many years while hoping they have already coped with the past, already forgiven. But the victim has to clearly acknowledge that the evil was committed on her, identify the person who is responsible for it and admit the damage done - so she has to face reality; otherwise forgiveness is just an illusion.

When various forms of denial are breaking down, various layers of suppressed emotions (especially grief and anger) are emerging. To give proper space to these emotions is an important part of the forgiving process.

\footnotetext{
${ }_{9}^{9}$ Cp.: KeSHGEGIAN, F.: Redeeming Memories. Nashville : Abingdon Press, 2000.

${ }^{10}$ Cp.: TUTU, D.: Bez odpustenia niet budúcnosti. Bratislava : Serafín, 2005, pg. 278; FORTUNE, M. M.: Preaching Forgiveness? pg.49-57. In: McCLURE, J. S. - RAMSAY, N. J. (Eds.): Telling the Truth. Cleveland, Ohio : United Church Press, 1998.; ARMS, M. F.: When Forgiveness Is Not the Issue in Forgiveness. pg. 107-128. In: FORTUNE, M. M. - MARSHALL, J. L. (Eds.): Forgiveness and Abuse. New York: The Haworth Pastoral Press, Inc., 2002, pg. 113-114.
} 
Grief is understandable especially in regard to loses that are the results of experienced trauma. It is this very damage (the debt that could not be paid off) that has to be mourned over. Trauma creates damage that could not be compensated; it is not possible to seat the previous state. Although many symptoms could be moderated or repaired, the recovery process will absorb a lot of energy, time and money that could be used in a totally different way. The process of grieving over loses is very painful and exhausting but it must not be repressed or skipped. The debt that is forgiven has to be acknowledged on the cognitive as well as on the emotional level - otherwise forgiveness would be an empty gesture.

It is also important to point out that forgiveness does not mean a state where pain has already disappeared. Acute states of grieving - accompanied by many tears, sorrowful moaning and feeling as if there is nothing except the wound - can fade in time; given the proper conditions it is possible to reduce the pain to a great extent, but not remove it totally. It is just a myth that those who forgave should smile and overflow with joy as if nothing hurt any more. Deep wounds will not stop hurting; although the pain will not be the center of the experience, it is quite probable that it will emerge from time to time. But the presence of pain is not a proof about the lack of forgiveness; it just manifests that the victim does not lose the natural and healthy sensitivity toward injustice. ${ }^{11}$

Apart from grief, anger also has its place in the forgiveness process. Many Christians regard anger as bad or sinful but the truth is that each emotion it good if we handle it properly. In addition anger is an especially important emotion because it helps us to identify injustice and mobilizes us to take action against it. When the victim of any form of violence feels anger, she expresses by it that what the offender did was in contradiction to her dignity, it was bad and destructive and he had no right to act in that way. Anger enables the victim to condemn evil and reject negative messages that the offender communicated to her through the way he behaved toward her. Anger helps the victim to get out of the position of victim and tear away from offender. ${ }^{12}$

Many Christians have problems with touching their anger and expressing it because they regard this emotion as unbiblical - as if it were in contradiction to love. However anger is biblical. Jesus himself is the example that love toward an enemy does not exclude anger. In confrontation with the Pharisees Jesus addressed them with harsh words: he called them

\footnotetext{
${ }^{11}$ Cp.: Allender, D. B. - LONGMAN III, T.: Pravá tvár lásky. Bratislava : Porta Libri, 2004, pg. 155-158; YANTZI, M.: Sexual Offending and Restoration. Waterloo, Ont. : Herald Press, 1998, pg. 125-128.

${ }^{12}$ Cp.: WOLBERT, W.: Odpušteni a sebeúcta. 2002, [online], [cited 2003-11-17], http://www. teologicketexty.cz/issue/2002/2-3/wolbert.xml; GRÜN, A.: Škola odpuštění. Kostelní Vydří : Karmelitánske nakladatelství, 2002, pg. 6-7, 11, 23, 36-37.
} 
hypocrites, snakes, sons of hell, fools and blind, cups full of extortion and excess, whited sepulchers full of dead men's bones (comp. Mth 23:13-33). Jesus did not pretend that everything is OK, he did not used nice words to protect their reputation. Biblical forgiveness is based on the commitment to speak the truth, clearly identifying the responsibility for the sin, expressing the indignation over the injustice and condemning the evil. Such forgiveness is the opposite of false compassion and clemency that tempt many people to pardon the offender.

It is necessary to realize that forgiveness does not mean pardoning the offender. We can pardon somebody who indirectly, without intention, caused some troubles (e.g. came late to the meeting because he had to solve unexpected and urgent things; or he canceled the term because he got ill). ${ }^{13}$

However the majority of people who behave in a violent and abusive way are fully responsible for their deeds. No brain, hormonal or psychological disorders, nor bad cultural models, pathological family upbringing or childhood traumas can sufficiently explain and pardon delinquent behavior. People cannot reach forgiveness through trying to understand the reasons of the offender's behavior and finding something that would pardon him. It would not be therapeutic nor ethical (moral and legal norms could otherwise be easily relativized). In addition, pardoning the offender would imply the innocence of the offender and make forgiveness unfounded. If the victim believes that the poor offender is not responsible for his deeds, then there is nothing to forgive. On the contrary - true forgiveness clearly indicates that offender is guilty, that he has no excuse or mitigating circumstances, and in fact there is no reason to pardon him. ${ }^{14}$

Victims also need to realize that forgiveness does not exclude punishing the offender. When preaching about forgiveness priests and pastors often mention examples of large-hearted people who forgave even the serious crimes. But preachers usually fail to mention an important fact that such examples of forgiveness took place in the context of justice: crimes were publicly disclosed (not kept in secret as it is usual in cases of abuse) and the offenders were called to responsibility for their deeds, convicted and punished.

Where a crime is committed, private solutions of the situation are not only insufficient but also often impossible. For these reasons the task of

\footnotetext{
${ }^{13}$ Cp.: WOLBERT, W.: Odpuštení a sebeúcta. 2002, [online], [cited 2003-11-17], http://www. teologicketexty.cz/issue/2002/2-3/wolbert.xml.

${ }^{14}$ Cp.: COYLE, C. T.: Forgiveness, Reconciliation and Healing. In: FORTUNE, M. M. - MARSHALL, J. L. (Eds.): Forgiveness and Abuse. New York : The Haworth Pastoral Press, Inc., 2002, pg. 96; INTERNATIONAL FORGIVENESS INSTITUTE About Forgiveness. 2005, [online], [cited 2005-02-30], <http://www.forgiveness-institute.org/html/about_forgiveness.h tm>; McMANUS, J.: Healing in the Spirit. Hampshire : Redemptorist Publications, 2002, pg. 185-186; WOLBERT, W.: Odpuštení a sebeúcta. 2002, [online], [cited 2003-11-17], http://ww w.teologicketexty.cz/issue/2002/2-3/wolbert.xml.
} 
confrontation, sentencing and punishing the offenders, as well as the task of protecting the victims have to be guaranteed by public authority.

Victims are uselessly confused by the request to forgive if they do not know that there is no contradiction between forgiveness and letting the offender bear responsibility for his deeds - although if it would mean reporting him, conviction, sentencing and loading him with probation conditions.

Punishing the offender means public rejection of his false demands toward a victim, and it contributes to the correction of negative messages that he implanted within victim. The punishment also expresses that violence and abuse can not be tolerated. The punishment serves as a warning not to repeat the crime ever again; so it is a kind of challenge to repentance. From the spiritual point of view punishment is even a form of mercy - as it rises out of interest in the good of the offender's soul which it would like to turn away from leading to hell (comp. Rev 3:19; 2 Cor 7:810 or Jacob 5:19).

From what has been said already we can conclude that anger could and has to serve the good - by restricting evil. The anger has an indispensable role in a process of forgiveness. It becomes bad, harmful or sinful only when it is excessive or insufficient (deficient). ${ }^{15}$

If man does not control his anger, he can become furious and see the only solution of injustice in revenge. While the biblical request of forgiveness allows people to punish an offender, revenge is forbidden. Many people do not realize that there is an essential difference between punishment and revenge.

The purpose of punishment is to protect and multiply the good both on the side of victims as well as on the side of offenders. The punishment is an expression of anger that condemns evil and at the same time serves as an expression of love that urges change. Through punishment the offender is confronted with truth; the darkness of his sin is brought to light and he is ashamed. He can refuse the truth, stay in denial and continue in the direction of spiritual death - or turn to truth and accept the conditions of life. The punishment could be uncomfortable, humiliating (abashing) or painful for the offender but it still serves the good - it restores justice and order, contributes to purifying offender's soul. ${ }^{16}$ The punishment is not intended to destroy the offender - it still respects the dignity of a man as a being that in spite of a crime committed is still capable of moral reflection and acting. The punishment still gives the offender a chance to change.

On the contrary revenge is merciless; it does not give him any chance to change - by which it also deletes any chance for reconciliation. The revenge destroys an enemy, not the evil (sin). It is bad, absurd and useless - it commits just another violence that cannot remove or reduce past trauma anyway.

\footnotetext{
${ }^{15}$ Cp.: PADOVANI, M. H.: Hojenie zranených emócií. Nitra : SVD, 1999, pg. 33-34.

${ }^{16}$ Cp.: WOJTYŁA, K.: Znameni odporu. Řím : Křestanská akademie, 1981, pg. 168.
} 


\section{DOI 10.2478/v10154-010-0019-1}

A man resorting to revenge is giving himself to a position of judge that does not belong to him. Forgiving man (man who forgives) gives up revenge - putting it to the hands of God (as the Bible recommends it in Rom 12:19). God takes seriously the debt that has been caused to victims. If an offender does not repent soon, until he is "on the earthly way" with the victim, God will finally demand him to pay off the whole debt until the last cent is paid (comp. Mth 5:25-26).

Repressing anger is the opposite of its excess but it is not less harmful than revenge. If a victim does not feel anger over what the offender has done to her, it could mean that she denies the reality of injustice and hurt or that she blames herself. If anger is not properly directed and expressed, then it not only blocks the forgiving process but also inhibits a restoration of self-respect and could transform into self-aggression or various psychological, somatic, psychosomatic or spiritual problems.

Only if one acknowledges the justness of anger in relation to evil, can one understand what is he forgiving. It is important to deal with anger honestly, perceive it, try to understand it and finally express it in a proper way. But it is not enough just to speak about anger; it is useful to release it in a safe and therapeutic manner. Only if anger is honestly dealt with is the victim prepared to confront the offender and get free from him. ${ }^{17}$

Finally, in regard to the relation between anger and forgiveness, it has to be added that forgiveness does not mean the total disappearance of anger. Many Christians suppose that a person who openly speaks about abusive experiences and uses even harsh words of just and reasonable anger, is more full of hatred than of forgiveness. Even victims themselves think that anger is proof of their inability to forgive and love their enemy. The opposite is the truth however. Where even a little sign of anger is missing when forgiveness is declared, forgiveness is probably just a sweet illusion. That illusion is even bigger when there are no signs of repentance on the side of offender. The Bible says: Awe before God is to hate evil. Toward pride, arrogance, bad way and mouth that wrest the truth, I feel hatred (Proverbs 8:13). Past or present evil will always activate a certain level of anger in a healthy man. ${ }^{18}$

What has been said up to now could be summarized into two rules: (1) to face truth instead of its denial and (2) make use of emotions instead of their devaluation - is a necessary part of the forgiving process. By ac-

\footnotetext{
${ }^{17}$ Cp.: PADOVANI, M. H.: Hojenie zranených emócií. Nitra : SVD, 1999, pg. 31-42; WOLBERT, W.: Odpušteni a sebeúcta. 2002, [online], [cited 2003-11-17], <http://www.teologicketexty.cz/issue/2002/2-3/wolbert.xml>.

${ }^{18}$ Cp.: DRATCH, M.: Forgiving the Unforgivable? : Jewish Insights into Repentance and Forgiveness. In: FORTUNE, M. M. - MARSHALL, J. L. (Eds.): Forgiveness and Abuse. New York : The Haworth Pastoral Press, Inc., 2002, pg. 19-20; BILICH, M. et al.: Shared Grace. New York : The Haworth Pastoral Press, 2000, pg. 104-109; ALLENDER, D. B. - LONGMAN III, T.: Pravá tvár lásky. Bratislava : Porta Libri, 2004, pg. 155-158, 185, 195-198.
} 
cepting these rules we create basic conditions in which forgiveness can take place. But it is important to realize that one will not start living according to these rules in a moment - rather he has to learn them and get used to them - for what he needs a lot of courage and strength. That is why we should respect the reality that forgiveness is a process.

In literature as well as in common conversation one can often meet with statements that forgiveness is a choice, an act of will, a question of making a decision, a question of willingness to give up something or leave something (most often it refers to giving up a revenge, hatred or anger itself, or to leaving a painful past or self-pity). ${ }^{19}$

I think that statements like these could be easily misunderstood. Under that decision or act of will people often imagine some isolated and simplified act - as if man decides to draw a fat dividing line in a defacement notebook or turn the list and continue on the clear page. Many people really believe that this is what exemplary forgiveness should look like - if somebody does not manage to get rid of the past at once, then he suffers guilt feelings from not forgiving or such remorse is addressed to him from outside, from various people. Although this remorse seems to be substantial and stir up much anxiety - it is not based on real guilt.

If we consider the fact that forgiveness is a process, then any linking of forgiveness with decision or an act of will or with willingness is proper only in relation to that process. In other words, forgiving person (person who forgives) shows the will or willingness to set off on a journey of forgiveness - so to learn to create in his inner and outside world conditions of justice and truth. Each person walks through this journey by her own tempo, according to her own individual possibilities and abilities.

Nobody has a right to accuse somebody of not forgiving. It could be said that wherever on the journey of forgiveness one is, in fact he already forgave; but at the same time his forgiveness does not yet need to be perfect. We can long for perfection, struggle for it, getting closer to it - but we can hardly reach it fully on the earthly journey. It seems that forgiveness is similar to the Kingdom of God, that here on the earth "already is" (to a certain extent) but at the same time "is not yet" (whole).

If every process has its beginning, middle and end, then something similar could be distinguished also in regard to forgiveness. It seems that awaking from denial is somewhere at the beginning of the forgiveness process. The middle of the process could be characterized by emotional and cognitive floatation with wound and the debtor. Clear distinguishing of truth and lie and the relative freedom from the offender and probably also from the consequences of the wound should dominate the end stage of the process.

\footnotetext{
${ }^{19}$ Cp.: McMANUS, J.: Healing in the Spirit. Hampshire : Redemptorist Publications, 2002, pg. 181-183, 185-186, 188-189, 194; BENNER, D. G.: Hojenie emocionálnych poranení. Nitra : Vydavatelstvo Nádej, 1992, pg. 111.
} 
This scheme is very simplified but it outlines an interesting fact - that the forgiveness process is parallel to the process of healing. I do not agree with those who preach that forgiveness is a condition of healing. Many victims who suffered some long-term consequences of trauma were told that they are not healed because they did not forgive. Such a statement is not only absurd but also totally insensitive. We would never dare to say something like this to somebody who suffers permanent physical consequences as a result of physical harm. But contrary to physical wounds, psychological wounds are often simplified and minimized - making victims responsible for the trauma consequences.

In some Christian circles forgiveness is presented almost as some magical instrument for inner healing, as a miraculous medicine on every wound and trouble. Victims then think that it is enough just to say a couple of magic words as "I forgive you" or just do some forgiveness ritual (ceremony) and from that moment everything would be changed, traumatic symptoms would disappear, broken relationships would be repaired, all will be happy and God will be satisfied. If this does not work victims feel disappointed and ashamed. They start blaming themselves or think they have made some mistake while saying the magic words or doing the ritual - perhaps they have not been concentrated enough or perhaps their love toward enemies or trust in God is not sincere or strong enough. Lasting consequences are then often interpreted as a sign of not being forgivingful (a sign that particular person has not forgive yet). ${ }^{20}$

I do not say that words and rituals of forgiveness are totally useless or bad. Such words could be said and rituals could be done many times during the forgiving process. But they are harmless only to extent to which they are not connected with an expectation that they will carry a person to the very end of the forgiveness process, to the state of freedom from the wound as well as from the offender. To reach such a state requires not only much time and effort but also the proper therapeutic environment. So forgiveness is not a condition or an instrument of healing; rather we can say that gradual moving forward in the process of healing naturally facilitates the process of forgiveness. But although one reaches a final stage of forgiveness, it does not mean that he will at the same time encounter perfect health. Health and the possibilities of its restoration on this earth are relative: some consequences could be permanent and it has nothing to do with not being forgivingful (with the fact whether the person forgave or not).

\footnotetext{
${ }^{20}$ Cp.: FORTUNE, M. M.: Preaching Forgiveness? In: McCLURE, J. S. - RAMSAY, N. J. (Eds.): Telling the Truth. Cleveland, Ohio : United Church Press, 1998, pg. 49-50; HORSFIELD, P.: Forgiving Abuse - An Ethical Critique. In: FORTUNE, M. M. - MARSHALL, J. L. (Eds.) Forgiveness and Abuse. New York : The Haworth Pastoral Press, Inc., 2002, pg. 55-56; YANTZI, M.: Sexual Offending and Restoration. Waterloo, Ont. : Herald Press, 1998, pg. 125-128; COLEMAN, M. A.: A Safe Place Nashville, TN : Vanderbilt Divinity School, 1998, [online], [cited 200507-14], <http://divinity.lib.vanderbilt.edu/Carpenter/papers/coleman.html>, pg. 42-52.
} 


\section{Senseless pressures regarding forgiveness}

There is one more dangerous tendency in regard of forgiveness: it is a tendency to push victims to forgive. Many Christians do not respect the fact that forgiveness is a process and that it has some conditions. When victims share their experiences, forgiveness is usually the first thing they are advised or asked to do. If the topic of forgiveness is not submitted at the first meeting, it is usually brought into conversation during the next few sessions. It is a common reaction of priests, relatives or friends.

Critical examination would disclose that hidden motives for such pushing are probably unwillingness to face uncomfortable truth and to stand actively on a side of justice. In practice it is usually manifested by unwillingness to listen to uneasy questions of victims and the emotions they feel. It is our unwillingness to help our neighbor to carry his burden that is too heavy for him and our indifference toward a fact that we will make his burden even heavier. Pushing victims to quick forgiveness is for many also a way to silence victims effectively, to hush up crime, to avoid the uncomfortable task to confront perhaps some important person; to avoid conflict, scandal or the court and retain a smooth face. People with such motives expect forgiveness to resolve everything and once and for all to close an uncomfortable topic. They do not want to be bothered by such problem any more and waste their precious time and energy. They do not want to burden themselves and at the same time they do not care about the burden of the victim. By pushing victims to forgiveness they want to get rid of their portion of responsibility in building a just and safe world. In better cases their motive is just the unawareness of somebody who would like to help but does not know how; forgiveness seems to be a good idea. ${ }^{21}$

The outside pressure on victims (to forgive) is often internalized. Victims identify with this pressure - they themselves wish to forgive quickly while other motives emerge. They want to meet the outside expectations thinking that otherwise they would not be good Christians and risk condemnation. Or they are afraid to be seen as "unhealed" or even "obsessed by the spirit of not forgiving" in the eyes of some Christians. In addition through quick forgiveness they could unconsciously avoid demanding therapeutic work - hoping forgiveness is a shortcut to healing. ${ }^{22}$

\footnotetext{
${ }^{21}$ Cp.: HORSFIELD, P.: Forgiving Abuse - An Ethical Critique. In: FORTUNE, M. M. - MARSHALL, J. L. (Eds.) Forgiveness and Abuse. New York : The Haworth Pastoral Press, Inc., 2002, pg. 54, 57-59; O'GRADY, R.: The Hidden Shame of the Church. Geneva, Switzerland : WCC Publications, 2001, pg. 33; DUFFY, E.: Forgiveness and Reconciliation in the Context of Child Sexual Abuse. In: CONWAY, E. - DUFFY, E. - SHIELDS, A. (Eds.): The Church and Child Sexual Abuse. Dublin : The Columba Press, 1999, pg. 68-70, 72.

${ }^{22}$ Cp.: HORSFIELD, P.: Forgiving Abuse - An Ethical Critique. In: FORTUNE, M. M. - MARSHALL, J. L. (Eds.) Forgiveness and Abuse. New York : The Haworth Pastoral Press, Inc., 2002, pg. 57-59; HEITRITTER, L. - VOUGHT, J.: Helping Victims of Sexual Abuse. Minneapolis : Bethany House Publishers, 1989, pg. 205-206, 208.
} 
Neither outside nor inside pressure can quicken forgiveness. Forgiveness is a process that has no shortcuts. In the same time forgiveness is a gift of God, a grace with which one can cooperate but not manipulate. As God gives his gifts in a proper time - each stage of forgiveness has its time. The last stage is characterized by the "fulfillment of time" for which the Bible as well as theology use Greek term "kairos". Kairos can not be enforced nor can it be planned or calculated - it does not have a chronological character. We do not know when this time will come; we only know that we can always prepare for it. The preparation consists of everything that contributes to justice, healing and maturing. When the wounds are deep (especially when they have been inflicted by crime) the process of forgiveness can be very slow and long-lasting; it can take years or even decades and we have to admit even a possibility that it will take a whole lifetime. It is necessary to respect this reality and approach victims with great patience. Instead of pushing to forgiveness we should patiently await the fulfillment of time and carefully accompany victims on the process of preparation for it. ${ }^{23}$

During a process of preparation various layers of denial are breaking down; truth comes to the surface with all emotions that were suppressed for a long time. It is a time when it gets clearer that offender's degrading messages are false and the victim's self-respect is gradually restoring itself. It is a time when boundaries against evil are established, justice is being renewed, and the victim gains inner strength. Only a stronger person can forgive. It has nothing to do with the strength of character but with the structure of power. If the relation between a victim and an offender is similar to a relation between a slave and master - it is unhealthy, unethical and unbiblical to expect the victim to forgive. When the victim possesses more power, she can take proactive stance toward the offender and freely offer forgiveness. ${ }^{24}$ In this regard it is useful to mention that the topic of forgiveness should not

\footnotetext{
${ }^{23}$ Cp.: DUFFY, E.: Forgiveness and Reconciliation in the Context of Child Sexual Abuse. In: CONWAY, E. et al (Eds.): The Church and Child Sexual Abuse. Dublin : The Columba Press, 1999, pg. 68-70, 72; FORTUNE, M. M. - MARSHALL, J. L. (Eds): Forgiveness and Abuse. New York : The Haworth Pastoral Press, Inc., 2002, pg. 2-3; BILICH, M. et al: Shared Grace. New York : The Haworth Pastoral Press, 2000, pg. 104-109.

${ }^{24}$ Cp.: DUFFY, E.: Forgiveness and Reconciliation in the Context of Child Sexual Abuse. In: CONWAY, E. - DUFFY, E. - SHIELDS, A. (Eds.): The Church and Child Sexual Abuse. Dublin : The Columba Press, 1999, pg. 68-70, 72; WOLBERT, W.: Odpušteni a sebeuicta. 2002, [online], [cited 2003-11-17], <http://www.teologicketexty.cz/issue/2002/2-3/wolb ert.xml>; HEIM, T. A. - RYE, M. S.: Forgiveness and Mental Health. In: FORTUNE, M. M. MARSHALL, J. L. (Eds.): Forgiveness and Abuse. New York : The Haworth Pastoral Press, Inc., 2002, pg. 46; FARLEY, W.: Evil, Violence, and the Practice of Theodicy. In: McCLURE, J. S. - RAMSAY, N. J. (Eds.) Telling the Truth. Cleveland, Ohio : United Church Press, 1998, pg. 17; KEENE, F. W.: Structures of Forgiveness in the New Testament. In: ADAMS, C.J. - FORTUNE, M.M. (Eds.) (1996). Violence Against Women and Children. New York : Continuum International Publishing Group, 1996, pg. 121-134.
} 
enter into the dialogue from the helper's initiative and never during the initial stages of therapy. Its proper place is in advanced or final stages of therapy, when conditions for it are sufficiently prepared.

When the phrase "Forgive!" or "I forgive" is used outside of the conditions of truth and justice, then it is just insolent hypocrisy or naive illusion. It is important to realize that if somebody forgives under pressure - he is doing nothing other than some act consisting of false ideas about forgiveness. Such an act can create a short-lived sense of release within victims, offenders and other interested persons - but from a long-term perspective it could bring nothing good. Forced and premature forgiveness is not a way of healing, peace and salvation for anybody.

In victims such "forgiveness" will probably cause a short circuit in the process of healing. It can block up access to emotions of grief and just anger and at the same time deepen the guilt feeling, depression and a risk of auto-aggression. In addition any pressure on the victim regarding forgiveness reminds her of the offender's approach and commits another abuse to the victim's soul. Through all this the cycle of violence (with all the negative messages coming from it and hitting a victim) gets stronger instead of weaker. So it is not surprising that forced forgiveness often influences various relations (therapeutic, pastoral, family or friend) in a bad way. It can also lead to a premature ending of therapy or spiritual direction or even to break-up a friendship. ${ }^{25}$

Regarding the offenders premature forgiveness lessens the motivation to the solid work that repentance demands. Christians should not offer forgiveness as a cheap grace (without requesting repentance) because it will not help offenders to change themselves. People sometimes offer quick forgiveness in a false hope that such "great love" will change the offender. Sometimes victims are told that if they will not forgive they hinder offender's healing or even his salvation. Such thinking is deceptive: with "unconditional forgiveness" we can nearly certainly predict that an offender will resist change. ${ }^{26}$

The question is what shall the victim do in a situation when the offender is explicitly asking ber for forgiveness? To find a response we have to remind ourselves of a parable that we analyzed at the beginning of this presentation - especially a finding that true forgiveness takes place in the

${ }^{25}$ Cp.: KeSHGEGIAN, F.: Redeeming Memories. Nashville : Abingdon Press, 2000, pg. 195; HEIM, T. A. - RYE, M. S.: Forgiveness and Mental Health. In: FORTUNE, M. M. - MARSHALL, J. L. (Eds.): Forgiveness and Abuse. New York : The Haworth Pastoral Press, Inc., 2002, pg. 46; BILICH, M. et al: Shared Grace. New York : The Haworth Pastoral Press, 2000, pg. 104-109.

${ }^{26}$ Cp.: HORSFIELD, P.: Forgiving Abuse - An Ethical Critique. In: FORTUNE, M. M. - MARSHALL, J. L. (Eds.) Forgiveness and Abuse. New York : The Haworth Pastoral Press, Inc., 2002, pg. 56; ARMS, M. F.: When Forgiveness Is Not the Issue in Forgiveness. In: FORTUNE, M. M. - MARSHALL, J. L. (Eds.): Forgiveness and Abuse. New York: The Haworth Pastoral Press, Inc., 2002, pg. 121. 
context of justice and truth - and that it is important to make a distinction between giving and receiving forgiveness.

\section{Confrontation and reconciliation in the context of forgiveness}

It could be said that the process of forgiveness is for a victim a time of preparing for giving forgiveness. But the moment the victim demonstrates giving forgiveness to the offender - is, I suggest, a moment of clear confrontation where the challenge to repent has its place. Here I need to point out that there are situations when direct (face to face) confrontation of the offender is not possible: the offender could be dead already, he can live far away or in an unknown place, or he is anonymous or he has refused a meeting. But also in such circumstances confrontation is in place and it is possible to realize it indirectly, e.g. in form of confrontational speech spoken in front of a witness (whether it is an understanding and compassionate human being or God or both).

Confrontation brings to light a depth of the evil that the offender committed, uncovers his manipulative lies and unauthorized interests, unveils hurt and damage that his behavior caused to the victim. Confrontation shames the offender and activates a reaction - intensifying the evil or repentance. It is quite possible that the offender will deny his responsibility, try to discredit the victim, make threats or even physically attack. The victim has to be prepared for it and not let herself get confused or scared away. Confrontation not only clearly distinguishes and rejects evil; it also sets boundaries to it.

If the perpetrator will not respect boundaries and will continue to live a life full of lies, deception, abuse or denial - creating a new "debt", then it is not possible to fully accomplish forgiveness. By the confrontation the offender is given a challenge to repent as well as a warning regarding the consequences of an absence of repentance. The victim can say: "I forgive you but I want to let you know that you will use the grace of this gift only if you will be prepared to receive it."

Granting forgiveness is neither necessary nor automatic - even if the offender would ask for it repeatedly. Some authors suggest that it is also possible to "withbold forgiveness." ${ }^{27}$ It does not mean that the victim is not prepared to grant forgiveness - rather it means that the offender is not prepared (disposed) to receive it. It can be a useful way to help the offender to

\footnotetext{
${ }^{27}$ Cp.: FORTUNE, M. M.: Forgiveness : The Last Step. In: ADAMS, C. J. - FORTUNE, M. M. (Eds.): Violence Against Women and Children. New York : Continuum International Publishing Group, 1996, pg. 201-206; HORSFIELD, P.: Forgiving Abuse - An Ethical Critique. In: FORTUNE, M. M. - MARSHALL, J. L. (Eds.) Forgiveness and Abuse. New York : The Haworth Pastoral Press, Inc., 2002, pg. 59-62; DRATCH, M.: Forgiving the Unforgivable? : Jewish Insights into Repentance and Forgiveness. In: FORTUNE, M. M. - MARSHALL, J. L. (Eds.): Forgiveness and Abuse. New York : The Haworth Pastoral Press, Inc., 2002, pg. 13, 16-17.
} 
see the reality, to emphasize the necessity of repentance and to protect the word forgiveness from abuse or the degradation of its proper sense. Such withholding of forgiveness is intended for the good of offender.

Even if the victim expressed forgiveness in front of the offender, it does not mean that she will thereby reconcile with him. Although forgiveness and reconciliation are connected terms, they are not identical. The difference between them is similar to the difference between granting and receiving forgiveness. Forgiveness is an activity that takes place on the side of the victim as an inner process the fruit of which can be eventually expressed outwardly but which does not depend on the repentance of the offender (only if in the sense that it can make it easier or more difficult). Reconciliation, on the contrary, requires the active involvement of both sides - but primarily the side of the offender because it essentially depends on his repentance. Without sincere repentance the offender can not receive the gift of forgiveness in a valid and effective way, nor can he reach reconciliation in the relationship with the victim or even with God. This principle is clearly shown in the biblical parable about the prodigal son (comp. Luke 15:18-20).

Confrontation is a place where conditions of reconciliation could be settled. The offender should confess his sins and accept his responsibility for wrongdoing without trying to excuse himself or blame the victim. He should also express regret over the hurt and damage he caused; seek therapeutic and spiritual help; make restitution by which he would actively support the process of the victim's recovery from the traumatic consequences (especially by paying for the expenses related to it). Of course he should relinquish any form of manipulation in relation to the victim and respect the other conditions set by the victim in order to protect her dignity, health and safety. ${ }^{28}$

Forgiveness could be an invitation toward reconciliation but not its blind and cheap guarantee. Forgiveness does not mean that the victim will automatically trust the offender. Love toward neighbor should not be nadve; it has to be careful and vigilant - it has to examine if the repentance of the offender is sincere. Lost trust can be regained only through honest repentance. If the offender does not respect boundaries and repeatedly trespasses conditions, reconciliation would be not only unhealthy but even dangerous. ${ }^{29}$ Withholding reconciliation in such circumstances is an

\footnotetext{
${ }^{28}$ Cp.: ALLENDER, D. B.: The Wounded Heart. Colorado Springs : NavPress, 1993, pg. 242; FORTUNE, M. M.: Forgiveness : The Last Step. In: ADAMS, C. J. - FORTUNE, M. M. (Eds.): Violence Against Women and Children. New York : Continuum International Publishing Group, 1996, pg. 204-205; TUTU, D.: Bez odpustenia niet budúcnosti. Bratislava : Serafín, 2005, pg. 280.

${ }^{29}$ Cp.: FREEDMAN, S. Forgiveness and reconciliation. In: Counselling \& Vallues. Falls Church: April 1998, vol. 42, no. 3, p. 200, pg 200-216; COYLE, C. T.: Forgiveness, Reconciliation and Healing. In: FORTUNE, M. M. - MARSHALL, J. L. (Eds.): Forgiveness and
} 
expression of love toward truth and life.

The victim has a right even to interrupt any contact with the offender (a hint for such step could be found even in the Bible - comp. Matthew 18:15-18 or Mark 6:7-12). Nobody knows for sure when it is appropriate to take such step; but it is possible that the time will come when this will be the only proper way to protect oneself or others (perhaps ones own children) against an unrepentant offender. But the victim should be prepared for the possibility that other relatives and friends will stay in contact with the offender, exercising an approach of false forgiveness to him while condemning victim's approach.

Finally it has to be added that the absence of repentance on the side of the offender need not be the only barrier to reconciliation. Because of some permanent consequences that the trauma leaves (e.g. flashbacks during any contact with the offender) full restoration of the relationship could sometimes be impossible. But nobody has a right to rebuke the victim for this.

There is no doubt that premature forgiveness hides too many dangers; it can create more damage then benefit both on the side of the victims as well as the offenders. But it can also have a negative impact on the wider community - on the family or friends of offenders and victims, or on other people who are somehow touched by the crime. Members of the community also need to deal somehow with the crime and trauma. Premature forgiveness will not help them to negotiate the problem but rather make them accomplices of the crime.

The last dangerous tendency is to consider forgiveness and reconciliation a private matter. Many Christians perceive forgiveness as a one-sided task for victims. There are even some psycho-spiritual recipes to forgiveness (e.g. five steps toward forgiveness; twelve steps toward forgiveness; the pyramid model of forgiveness; four phases' model of forgiveness etc). Except for the fact that they are quite simplified and in some points even deceptive - their common feature is that they ignore the ethical and community dimension of the crime and put the responsibility for solving the crime's consequences exclusively on the shoulders of the victim.

Such recipes are victim oriented - the victim has to understand why the abuse happened and what kind of consequences it brought, and she is to solve them on a psycho-spiritual basis. Forgiveness is reduced to a psycho-spiritual act which will bring a resolution of the crime in a sense of inner freedom.

There is no doubt that the theory and practice of forgiveness is to a large extent separated from the ethical and social frame. People have to realize that such a frame is essential if forgiveness is to be meaningful and bring an effective solution. In the context of the crime, the privatization of forgiveness and reconciliation is absolutely inappropriate. The crime not

Abuse. New York : The Haworth Pastoral Press, Inc., 2002, pg. 97-98. 
only harms the primary victims but it also presents a violation of basic ethical norms that are protected by the laws of the state. In an ethical frame a crime is understood as a problem of the community - as a situation in which one member of the community treated another member badly - and so also a response to the crime should be a response of the community. The Bible says that all Christians create "one body of Christ" and when one member suffers, all the members suffer with him (comp. 1 Cor 12:12-27). Faith is something inward and private, but it has to be witnessed outwardly by respecting and protecting ethical norms. Here we touch the need of justice, prevention and solidarity.

The Church as well as the secular community has to take a clear stance (attitude) toward the crime and look for the right way to forgive and reconcile with the offender (from its own position but with regard to the victims). It also plays an important role in the process of forgiveness and reconciliation that both the victim and the offender have to go through. $^{30}$ There are many ways members of the community can complicate this process and many ways how they can facilitate it. The latter are always the ways in which the community participates in making justice.

\section{References}

Allender, D. B. - LONGMAN III, T.: Pravá tvár lásky. Bratislava : Porta Libri, 2004.

ALLENDER, D. B.: The Wounded Heart. Colorado Springs : NavPress, 1993. ARMS, M. F.: When Forgiveness Is Not the Issue in Forgiveness. pg. 107128. In: FORTUNE, M. M. - MARSHALL, J. L. (Eds.): Forgiveness and Abuse. New York: The Haworth Pastoral Press, Inc., 2002.

BENNER, D. G.: Hojenie emocionálnych poranení. Nitra : Vydavatelstvo Nádej, 1992.

BILICH, M. - BONFIGLIO, S. - CARLSON, S.: Shared Grace. New York : The Haworth Pastoral Press, 2000.

COLEMAN, M. A.: A Safe Place Nashville, TN : Vanderbilt Divinity School,

\footnotetext{
${ }^{30}$ Cp.: HORSFIELD, P.: Forgiving Abuse - An Ethical Critique. In: FORTUNE, M. M. - MARSHALL, J. L. (Eds.) Forgiveness and Abuse. New York : The Haworth Pastoral Press, Inc., 2002, pg. 51-64, 68; ARMS, M. F.: When Forgiveness Is Not the Issue in Forgiveness. In: FORTUNE, M. M. - MARSHALL, J. L. (Eds.): Forgiveness and Abuse. New York: The Haworth Pastoral Press, Inc., 2002, pg. 109, 112; FORTUNE, M. M.: Preaching Forgiveness? In: McCLURE, J. S. - RAMSAY, N. J. (Eds.): Telling the Truth. Cleveland, Ohio : United Church Press, 1998, pg. 49-57; COlEMAN, M. A.: A Safe Place Nashville, TN : Vanderbilt Divinity School, 1998, [online], [cited 2005-07-14], <http://divinity.lib.vanderbilt.edu/Ca rpenter/papers/coleman.html>, pg. 42-52; TUTU, D.: Bez odpustenia niet budúcnosti. Bratislava : Serafín, 2005, pg. 280-281.
} 
1998, [online], [cited 2005-07-14], <http://divinity.lib.vanderbilt.edu/Ca rpenter/papers/coleman.html>.

COYLE, C. T.: Forgiveness, Reconciliation and Healing. pg. 95-105. In: FORTUNE, M. M. - MARSHALL, J. L. (Eds.): Forgiveness and Abuse. New York : The Haworth Pastoral Press, Inc., 2002.

DONGHI, A.: Hle, všechno tvořím nové. Kostelní Vydří: Karmelitánske nakladatelství, 2002,

DRATCH, M.: Forgiving the Unforgivable? : Jewish Insights into Repentance and Forgiveness. Pg. 7-24 In: FORTUNE, M. M. - MARSHALL, J. L. (Eds.): Forgiveness and Abuse. New York : The Haworth Pastoral Press, Inc., 2002.

DUFFY, E.: Forgiveness and Reconciliation in the Context of Child Sexual Abuse. pg. 67-75. In: CONWAY, E. - DUFFY, E. - SHIELDS, A. (Eds.): The Church and Child Sexual Abuse. Dublin : The Columba Press, 1999.

FARLEY, W.: Evil, Violence, and the Practice of Theodicy. pg. 11-20. In: McCLURE, J. S. - RAMSAY, N. J. (Eds.) Telling the Truth. Cleveland, Ohio : United Church Press, 1998,

FORTUNE, M. M. - MARSHALL, J. L. (Eds): Forgiveness and Abuse. New York : The Haworth Pastoral Press, Inc., 2002,

FORTUNE, M. M.: Violence in the Family. Cleveland : The Pilgrim Press, 1991. FORTUNE, M. M.: Forgiveness : The Last Step. pg. 201-206. In: ADAMS, C. J. - FORTUNE, M. M. (Eds.): Violence Against Women and Children. New York : Continuum International Publishing Group, 1996.

FORTUNE, M. M.: Preaching Forgiveness? pg.49-57. In: McCLURE, J. S. RAMSAY, N. J. (Eds.): Telling the Truth. Cleveland, Ohio : United Church Press, 1998.

FREEDMAN, S. Forgiveness and reconciliation. In: Counselling \& Vallues. Falls Church: April 1998, vol. 42, no. 3, p. 200, 17 p.

GRÜN, A.: Škola odpuštění. Kostelní Vydří : Karmelitánske nakladatelství, 2002.

HEIM, T. A. - RYE, M. S.: Forgiveness and Mental Health. pg. 29-49. In: FORTUNE, M. M. - MARSHALL, J. L. (Eds.): Forgiveness and Abuse. New York : The Haworth Pastoral Press, Inc., 2002.

HEITRITTER, L. - VOUGHT, J.: Helping Victims of Sexual Abuse. Minneapolis : Bethany House Publishers, 1989.

HORSFIELD, P.: Forgiving Abuse - An Ethical Critique. pg. 51-70. In: FORTUNE, M. M. - MARSHALL, J. L. (Eds.) Forgiveness and Abuse. New York : The Haworth Pastoral Press, Inc., 2002.

INTERNATIONAL FORGIVENESS INSTITUTE About Forgiveness. 2005, [online], [cited 2005-02-30], <http://www.forgiveness-institute.org $/ \mathrm{html}$ /about_forgiveness.htm>.

CATHECHISM OF CATHOLIC CHURCH. (Slovak translation). Trnava : Spolok svätého Vojtecha, 1998. 
DOI 10.2478/v10154-010-0019-1

KEENE, F. W.: Structures of Forgiveness in the New Testament, pg. 121134. In: ADAMS, C.J. - FORTUNE, M.M. (Eds.) (1996). Violence Against Women and Children: A Christian Theological Sourcebook. New York : Continuum International Publishing Group, 1996.

KESHGEGIAN, F.: Redeeming Memories. Nashville : Abingdon Press, 2000.

McMANUS, J.: Healing in the Spirit. Hampshire : Redemptorist Publications, 2002.

O'GRADY, R.: The Hidden Shame of the Church. Geneva, Switzerland : WCC Publications, 2001.

PADOVANI, M. H.: Hojenie zranených emócií. Nitra : SVD, 1999.

PARKINSON, P.: Child Sexual Abuse and the Churches. London : Hodder \& Stoughton, 1997.

PARKINSON, P.: What Does Lord Require of Us? Melbourne : Paper for the Australasian Christian Legal Convention, February 2001, [online], [cited 2004-01-04], <http://www.cls.org.au/convention7.htm>.

TUTU, D.: Bez odpustenia niet budúcnosti. Bratislava : Serafín, 2005.

WOJTYŁA, K.: Znamení odporu. Řím : Křestanská akademie, 1981.

WOLBERT, W.: Odpušteni a sebeuicta. 2002, [online], [cited 2003-11-17], $<$ http://www.teologicketexty.cz/issue/2002/2-3/wolbert.xml>.

YANTZI, M.: Sexual Offending and Restoration. Waterloo, Ont. : Herald Press, 1998. 